March 6, 1985

Dr. R.J. Bourchier

Executive Director

\section{Dear Bob,}

I was interested in your letter regarding bio-control agents in the February issue of the Chronicle. It reminded me of our conversation on the subject last fall, just after the Executive meeting. Certainly the limited market potential for bio-control agents in forestry must be regarded as a serious obstacle to eventual large scale production and use of these agents. The current high costs and low demand of these agents will of course ensure that the cost will probably remain high and the demand low. The two are strongly interrelated. Last year, the first two virus control agents were registered for use against two forest pests, Douglas-fir tussock moth and red-headed pine sawfly. At present the only Canadian source for these viruses is a Canadian Forestry Service lab (Forest Pest Management Institute at Sault Ste. Marie), and understandably they are quite costly to produce under such circumstances. To date, the private sector has shown little or no interest in producing and marketing these agents, and yet until their production is commercialized, the possibility that they will be used on a large operational scale is dim.

Your suggestion of a joint government industry effort to manufacture these agents deserves serious thought. There are a number of so-called bio-control agents whose potential will never be legitimately tested until we can move to the pilot operational scale. To take advantage of the potential of some of these agents as "population regulators" rather than "foliage protection agents", they must be available in sufficient quantity to carry out testing on a large operational scale. Fifty hectare tests will tell us very little about their potential. I mention viruses because I believe these are agents which could provide significant long term benefits in pest control if used on a much larger scale than at present. Another bio-control agent which has reached the stage of larger scale testing is the egg parasite, Trichogramma. The three-year program in Ontario to develop this technology has demonstrated that it can substantially reduce spruce budworm egg and larval populations. The pilot production facility at University of Guelph has developed and improved the production technology on a small scale. The program is now at the point where production and field testing should be scaled up substantially. Obviously this is an opportunity which could be seized by a government-industry corporation.

For your information, I am enclosing a copy of the paper I presented last fall to the provincial Deputies of Forestry \& Environment and several of the federal Depu- ties or Assistant Deputy Ministers. This seminar was sponsored by CCREM and I understand, the proceedings of the session are going to press this week, so they should be out shortly. Although my paper focusses on "policy problems", I recognize that the low demand for pesticides in the forestry sector is a very critical constraint on the whole developmentregistration process.

There are a couple of interesting developments on the B.t. scene recently which relate to the point in your letter.

1. Zoecon (Thuricide) has contracted with Quebec to do a feasibility study in 1985 on the establishment of a B.t. production facility in Quebec (Montreal). Obviously they want to be ready for 1987 when they go $100 \%$ B.t.

2. Chemagro has bought the rights to produce and market the B.t. products made by Biochem - Futura, Novabac, etc. I believe this is the first serious move by a chemical manufacturer into the B.t. field. Chemagro has a production plant for B.t. at Concord, north of Toronto.

Sincerely,

J.R. Carrow, Chairman

Forest Science and Technology Board

January 28, 1985

The Editor

The Globe and Mail

Toronto, Ontario

\section{Dear Sir:}

I am writing about your special "Report on Canada I" published January 25, 1985. Writer Kimberley Noble gave a good review of the forest products sector noting its importance to the Canadian economy and the present difficulties faced by the industry. If any criticism were to be made of her article, one would have to mention the scant attention she gave to the need for Canadian governments and industry to invest more in forest renewal. This must be done to ensure that the forest resource can continue to contribute strongly to our economic well-being. It provides one job in ten in Canada. We cannot afford to have it do less. While manufacturing employment in the sector will diminish with modernization, there is a lot of useful, productive work to be done in planting and tending forests for the future.

Many Canadians are not aware of the importance of the forests and forestry. The Canadian Institute of Forestry is trying hard to change that situation. However our efforts are often hampered by the way statistics are presented. The tables of "Key Data" for each province and the "Key Indicators" table on page R1 make no mention of forest products output. Motor vehicles, steel ingots and mineral production are all there but no forest products are mentioned. It is tragic that so many people will look over those tables and come away with a distorted view of what drives our economy.

Yours truly,

R.J. Bourchier

Executive Director

Canadian Institute of Forestry

March 25, 1985

Mr. R.J. Bourchier

Executive Director

Canadian Institute of Forestry

\section{Dear Mr. Bourchier:}

The Honourable Flora MacDonald has asked me to reply to your letter of February 8,1985 , regarding traineeships under the Canada-Mexico Exchange Program for Young Specialists and Technicians.

Indeed, forestry is an area in which Canada has much to offer and is currently being offered to Mexican trainees recruited through the Mexican National Science Council.

Your suggestion to allow Canadians access to traineeships in certain aspects of forestry practices in Mexico is well taken. We shall soon meet with officials of the Mexican National Science Council and propose that forestry be included in the areas of interest to Canada for future programs.

Thank you for your suggestions and for the interest you have shown in this Program.

Yours sincerely,

Monique Séguin

Departmental Assistant

Office of the Minister Employment and Immigration

le 4 avril 1985

Monsieur Luc Pouliot

Vice-Président

Section Champlain

Monsieur,

J'accuse réception de votre lettre du 19 décembre 1984 dans laquelle vous portez à mon attention l'importance du Bois de Belle-Rivière comme centre éducatif.

II me fait plaisir de vous informer que la Société immobilière du Canada (Mirabel) limitée a entrepris les démarches nécessaires afin d'assurer la continuité de activités à caractère récréatif de ce centre d'interprétation. J'espère que ces démarches seront des plus fructueuses.

Veuillez agréer, Monsieur, l'expression de mes sentiments distingués.

Roch La Salle Minister Public Works Canada 
April 1, 1985

Mr. A.B. Anderson, RPF

2547 Ottawa Avenue,

West Vancouver, B.C.

V7V 2T3

\section{Dear Andy:}

This is your noble President replying to your March 8th letter to Bob Bourchier re. Affiliate Membership.

The democratic process has prevailed in the question of membership of technicians et al being one of active or affiliate members on application for CIF enrollment. This is not to say that any indicated majority of directors at the 1984 annual meeting favoured a change in status and recognition of technician membership. The general meeting motion to hold a ballot vote on the question indicated much mixed feeling on the question. The outcome of the ballot will be the deciding factor, very shortly.

I appreciated your concern letter Andy, and other correspondence from other members in the same vein.

I personally do not favour a change; I do think the existing bylaws allow Sections to initiate elevation of Affiliates to Active member status if the Sections would pursue this route diligently.

I am sorry to hear you are not well Andy, and I hope it is something temporary. Best personal regards.

Sincerely

J.D. Clark, RPF

President
March 29, 1985

Dr. Jacques Poirier, President

The Canadian Federation of

Professional Foresters' Association

Dear Mr. Poirier,

I refer to your letter of March 6, 1985 concerning professional foresters as guarantors on passport applications.

As it has been explained in reply to previous representations made by your provincial affiliations, there is no special status attached to those categories of persons eligible to act as passport guarantors nor is there any adverse reflection on those groups not included on the list. The approved guarantor list is designed with two objectives in mind: first, to make the list broadly enough based to ensure that all Canadian citizens have ready access to one of the guarantors in their community; and second, to keep the categories to manageable proportions so that the Passport Office can, with minimal cost and without disrupting rapid service, carry out the necessary security review and checks of the applicant and the guarantor.

The qualifications of your membership and the role exercised by your members in the many forestry based communities in Canada are recognized. There is no indication from the public, however, that the list of persons eligible to act as guarantors is not sufficiently extensive to ensure that all Canadians have access to a guarantor in their community.

Although my reply does not comply with your request for inclusion of professional foresters on the guarantor list, hope that this reiteration of passport policy with regard to guarantors is satisfactory.

Yours sincerely, Joe Clark

Secretary of State for External Affairs

\section{Dr. J. Roderick Carrow Appointed Dean of Forestry at the University of Toronto}

The University of Toronto has appointed J. Roderick Carrow dean of the Faculty of Forestry for a six-year term, effective September 3, 1985 .

Dr. Carrow has combined a career in research and administration, and has established a reputation in this country and abroad as an expert in his field of forest entomology, the study of forest insects.

Since 1982, Carrow has been Assistant Deputy Minister, Forest Resources with the New Brunswick Department of Natural Resources. Prior to that, he was supervisor of the Pest Control Sector of the Ministry of Natural Resources in Toronto for five years. From 1967 to 1977 he worked as a research scientist and project leader for the Canadian Forestry Service of Environment Canada in Victoria.

A graduate of University of Toronto Schools, he received a B.Sc. from the University of Toronto (1961), a M.Sc. in zoology from the University of British Columbia (1967), and a Ph.D. in entomology from Cornell University (1971). From 1975 to 1982 he was a guest lecturer at Simon Fraser University.

Carrow is a member of the Ontario Professional Foresters Association and Vice-President of the Canadian Institute of Forestry. He has been involved in public forestry education with the Ontario Forestry Association and the Science Teachers Association of Ontario.

George Connell, President of the University of Toronto, said, "Dr. Carrow has the qualifications necessary to lead the Faculty of Forestry through one of the most exciting and important periods in its history." 